\title{
Manfaat pengembangan desa wisata dari aspek alam, sosial budaya, spiritual, dan ekonomi di kabupaten tabanan
}

\author{
Agus Muriawan Putra' ${ }^{1)}$, I Nyoman Jamin Ariana ${ }^{2)}$ \\ Program Studi Sarjana Terapan Pengelolaan Perhotelan Fakultas Pariwisata \\ Universitas Udayana \\ Denpasar \\ Email: muriawan@unud.ac.id
}

\begin{abstract}
Abstrak
Penelitian ini berfokus pada manfaat desa wisa ta dari a spek alam, sosial budaya, spiritual, dan ekonomi dari 3 (tiga) desa wisa ta sebagai lokasi penelitian, yaitu: Desa Wisata Tista, Desa Wisa ta Bongan, dan Desa Wisata Penatahan, Kabupaten Tabanan. Dengan mengetahui manfaat pengembangan desa wisa ta, sehingga dapat berkelanjutan (sustainable) serta dapat menjaga kelestarian a set-aset yang dimilikioleh de sa wisa ta. Pendekatan kualitatif dengan perpaduan Focus Group Discussion (FGD) digun akan un tuk men emukan model secara naturalis sesuaidengan keadaan serta manfa at desa wisa ta berkelanjutan di Kabupaten Tabanan. Hasil analisis da ta ditampilkan secara deskriptif kualitatif yang menyajikan manfaat pengembangan desa wisa ta, hasil observasi, da nhasil stu di la pangan. Hasil dari penelitian ini a dalah bahwa terdapat manfaat y ang signifikan pengembangan desa wisa ta terhadap aspek a lam, a spek sosial budaya, a spek spiritu al, d an a spek ekonomi, di mana daria nalisis data menyatakan bahwa manfaat terbesar dari a spek a lam adalah "kesa daran masyarakat dalam membuang sampah" sebesar 78\%, manfaat terbesar dari a spek ekonomi a dalah "tumbuhnya UMKM" sebesar 71\%, manfaat terbesar dari a spek spiritual a dalah "perawatan Tempat Suci" sebesar $88 \%$, dan manfaat terbesar dari aspek sosial budaya a dalah "mengh ormati tra disi da n budaya" sebesar $83 \%$. Desa wisata dapat menjaga dan mempertahankan kehidupan masyarakat. Pengembang an de sa wisata berdampak positif terhadap alam, sosial/budaya, spiritual, ekonomi. ${ }^{1}$
\end{abstract}

Kata Kunci: Desa Wisata, Manfaat Pengembangan, Pariwisata Kerakyatan Berkelanjutan, Partisipasi Masyarakat

\section{PENDAHULUAN}

Penelitian ini berfokus pada manfaat pengembangan desa wisata pada aspek alam, aspek sosial budaya, aspek spiritual, dan aspek ekonomi dari 3 (tiga) desa wisata sebagai lokasi penelitian, yaitu: Desa Wisata Tista, Kecamatan Kerambitan, Desa Wisata Bongan, Kecamatan Tabanan, dan Desa Wisata Penatahan, Kecamatan Penebel, Kabupaten Tabanan, di mana saat ini banyak sekali tumbuh dan berkembang desa wisata yang merupakan model pengelolaan dan pengembangan pariwisata di pedesaan yang berbasis pada peran serta masyarakat desa. Pembangunan berwawasan kerakyatan lebih mengedepankan peningkatan ekonomi rakyat dan pemberdayaan masyarakat. Desa wisata berupa kawasan pedesaan yang memiliki beberapa karakteristik khusus yang layak untuk menjadi daerah tujuan wisata. Masyarakatnya masih memiliki tradisi dan budaya, makanan khas, sistem pertanian, dan sistem sosial turut mewarnai 
sebuah kawasan desa wisata. Termasuk sumber daya alam dan lingkungan alam yang masih asli dan terjaga merupakan salah satu faktor penting dari sebuah kawasan desa wisata.

Penelitian yang berjudul "Integrated Rural Tourism: Concepts and Practice", Penulis Mary Cawley, Desmond A. Gillmor, dalam Annals of Tourism Research (2008), mengacu pada konsep yang berkaitan dengan pembangunan alternatif dalam menekankan pendekatan bottom-up yang melibatkan pemangku kepentingan lokal secara terpusat dalam mengejar dan yang didasarkan pada sumber daya fisik, ekonomi, sosial, dan budaya lokal, yang berupaya merangkul keragaman pemangku kepentingan dan sumber daya ini dengan memanfaatkan berbagai literatur ilmu sosial untuk merancang model pariwisata pedesaan terpadu [1]. Hal ini, didukung oleh pengertian desa wisata yang menyatakan perpaduan antara atraksi alam, budaya, dan kreativitas masyarakat setempat didukung oleh akomodasi dan fasilitas lainnya, yang dapat menarik minat wisatawan untuk berkunjung (Antara, 2016) [2]. Perkembangan desa wisata akan menimbulkan aktivitas masyarakat, aktivitas wisatawan, dan juga stakeholders lainnya. Selain itu, juga akan terjadi pemanfaatan lahan, interaksi masyarakat lokal dengan wisatawan, terjadinya pertemuan budaya yang berbeda, sehingga akan menimbulkan pengaruh atau dampak dalam aktivitas tersebut, baik secara langsung maupun tidak langsung [3].

Pengelolaan desa wisata yang profesional dan memperhatikan daya dukung lingkungan tentunya akan menimbulkan dampak yang positif dan begitu pula sebaliknya, sehingga masyarakat dalam pengembangannya tidak hanya semata-mata hanya melihat dari sisi ekonomi saja terhadap pengembangan desa wisata, perlu juga diperhatikan aspek-aspek lainnya agar pengembang an desa wisata menuju pengembangan yang berkualitas dan berkelanjutan. Kebaruan dari penelitian ini dan juga sekaligus sebagai tujuan dari penelitian ini adalah untuk menganalisis manfaat pengembang an desa wisata secara langsung terhadap aspek alam, aspek sosial budaya, aspek spiritual, dan juga aspek ekonomi di Kabupaten Tabanan [4].

\section{TINJAUAN PUSTAKA}

Bab ini menguraikan tentang literatur yang digunakan untuk memudahkan dalam memahami dengan jelas uraian dalam penelitian ini berkaitan dengan topik yang diangkat, sehingga memudahkan memahami uraian yang disusun. Berikut literatur dari penelitian sebelumnya yang digunakan, yaitu:

Penelitian yang berjudul "A Pattern Of Rural Tourism In The Songkhla Lake Basin, Thailand", Penulis Prachyakorn Chaiyakot dan Parichart Visuthismajarn dalam International Journal of Management \& Information Systems (2012) menyatakan tujuan dari artikel ini adalah untuk mengetahui pola desa wisata yang selaras dengan Sumber Daya Songkhla Lake Basin (SLB) di Thailand Selatan. Metode yang digunakan dalam pengumpulan data dilakukan melalui survei lapangan (observasi), Focus Group Discussion (FGD) yang melibatkan pemangku kepentingan pariwisata, dan kuesioner dengan 400 responden wisatawan, serta menggunakan teknik snowball sampling untuk ahli Songkhla Lake Basin (SLB).

Kajian ini menemukan bahwa Sumber Daya Wisata Songkhla Lake Basin terletak di daerah kaki bukit dataran rendah, di pantai, dan di danau. Terdiri dari cara hidup yang alami, menganut kepercayaan Buddhis, keindahan alam, benda-benda suci, cerita rakyat, situs arkeologi, dan sejarah. Wisatawan yang mengunjungi lokasi wisata di Songkhla Lake Basin (SLB) dan ditemukan bahwa lima besar tujuan berwisata di lokasi Songkhla Lake Basin (SLB) adalah sebagai berikut: $84 \%$ untuk rekreasi, 9\% untuk wisata edukasi, 4,8\% untuk melihat kerabat, 2,5\% untuk 
pertemuan/pelatihan/seminar, dan 1,8\% untuk melihat hal baru. Lima besar kegiatan wisata yang dipilih wisatawan selama berwisata di Songkhla Lake Basin (SLB) adalah sebagai berikut: 55\% untuk kegiatan ekowisata, 35,3\% untuk kegiatan wisata budaya, 33\% untuk kegiatan wisata arkeologi dan sejarah, 28,8\% untuk belanja, dan 27,3\% untuk kegiatan pariwisata lainnya [5].

Penelitian yang berjudul " A New Pattern of Sustainable Tourism Development in Taiwan", Penulis Wei-San Su, Cheng-Hung Huang, Chao-Chun Hsu dan Lan-Fang Chang dalam International Journal of Organizational Innovation (2017) menyatakan tujuan dari artikel ini adalah untuk memberikan informasi tentang bagaimana menerapkan pembangunan pariwisata berkelanjutan secara sistematis dan cepat di kota-kota yang ingin menjadi kota Cittaslow, menyelidiki faktor-faktor yang menghambat mereka untuk memperoleh sertifikasi Cittaslow, dan mengevaluasi kesesuaian kota-kota Taiwan terpilih sebagai kandidat Cittaslow.

Penelitian ini menggunakan metode wawancara semi terstruktur, wawancara di tempat, survei kuesioner.

Penelitian ini menghasilkan Konsep Cittaslow yang didasarkan pada konsep slow food dan konsep ini dikembangkan lebih lanjut dengan merambah ke kota dan bidang pariwisata. Gerakan slow food dimulai oleh penulis Italia Carlo Petrini pada tahun 1989 untuk memboikot rantai restoran cepat saji McDonald's. Salah satu tujuan utama dari Cittaslow adalah untuk mempromosikan gagasan slow food untuk masyarakat lokal untuk mewujudkan tujuan ekogastronomi dalam kehidupan sehari-hari masyarakat. Peters (2006) mencatat bahwa orang harus memperhatikan penerapan berbagai faktor untuk memperlambat perjalanan, melakukan sesuatu dengan kecepatan yang tepat, mengubah sikap tentang penggunaan waktu, dan intinya mengejar kualitas daripada kuantitas (Dickinson et al., 2011). Wisatawan harus menikmati perjalanan sebagai bagian dari liburan, belajar tentang budaya lokal dari tujuan perjalanan, bersantai, dan meminimalkan dampak negatif yang dibuat pada penduduk lokal dan lingkungan serta mendorong pengembangan pariwisata berkualitas tinggi (Lumsdon, \& McGrath, 2011). Cittaslow diyakini mampu mencegah atau menunda dampak negatif modernisasi terhadap masyarakat. Konsep Cittaslow secara langsung berkaitan dengan pembangunan berkelanjutan dari lingkungan lokal karena berfokus pada pelestarian sejarah penduduk setempat, lingkungan alam, nilai-nilai sosial dan budaya, dan pembangunan ekonomi [6].

Penelitian yang berjudul "Chinese Rural Tourism Development: Transition in The Case of Qiyunshan, Anhui", Penulis Ping Li, Chris Ryan, dan Jenny Cave dalam Tourism Management (2015) menyatakan tujuan dari artikel ini adalah untuk menggambarkan, menilai, dan mengevaluasi bagaimana pariwisata telah berkembang di desa di bawah kebijakan pedesaan Cina saat ini. Metode observasi, wawancara, dan pendekatan fungsionalis, yaitu: para pemangku kepentingan membentuk jaringan status yang dihubungkan oleh berbagai peran. Hasil peneltiian mengungkapkan komponen kunci dari strategi ini adalah peran kemitraan sektor swasta-negara dan diharapkan ini akan mendorong kebijakan pedesaan pengentasan kemiskinan. Oleh karena itu, studi ini membantu membangun pengetahuan yang ada tentang persepsi pemangku kepentingan tentang dampak pariwisata di komunitas pedesaan Tionghoa.

Tosun (2000) menyatakan, partisipasi masyarakat di beberapa daerah berkembang telah digunakan untuk membantu warga setempat memperoleh manfaat ekonomis dengan melibatkan mereka dalam pengambilan keputusan, sehingga dapat berkontribusi pada modal sosial lokal dengan meningkatkan keterampilan dan pemahaman lokal. Kebijakan pemerintah di tingkat lokal 
dapat berubah dengan baik dalam menanggapi tuntutan masyarakat lokal dan ini telah dibuktikan di lokasi lain (Gu \& Ryan, 2010; 2013).

Cina memiliki cita-cita sistem pasar sosialis harus didistribusikan kepada semua pemangku kepentingan dalam pariwisata termasuk penduduk dan bukan hanya kepentingan perusahaan. Hal ini, tidak hanya berkaitan dengan harga yang akan dikenakan tetapi juga dengan biaya ketika memasuki sebuah desa kuno dengan kesempatan kerja diciptakan bagi penduduk lokal, serta pendapatan yang mereka peroleh (Chen dkk., 2013; Wu et al., 2013) [7]. Penelitian yang berjudul "Livelihood Sustainability in A Rural Tourism Destination-Hetu Town, Anhui Province, China", Penulis Ming Ming Sua, Geoffrey Wallb, Yanan Wangc, Min Jin, dalam Tourism Management (2019) mengemukakan sebuah desain penelitian mix method. Wawancara aktor kunci dan survei penduduk fokus pada mereka yang terlibat langsung dalam aspek pariwisata. Observasi lapangan untuk memahami partisipasi dalam pariwisata dan keterlibatan dalam kegiatan ekonomi lainnya. Juga dipergunakan convenience sampling untuk peserta non pariwisata.

Penelitian ini telah menerapkan kerangka mata pencaharian berkelanjutan yang direstrukturisasi untuk menguji dampak pariwisata terhadap keberlanjutan mata pencaharian pedesaan di Kota Hetu, Provinsi Anhui, Cina. Penduduk menunjukkan tingkat dukungan yang tinggi untuk pengembangan pariwisata. Hubungan sinergis antara pariwisata dan kegiatan ekonomi tradisional yang diwakili oleh pertanian dan pekerjaan lokal, di mana penduduk telah mengembangkan strategi multi mata pencaharian, menggabungkan pariwisata bersama dengan kegiatan tradisional mereka, yang telah meningkatkan keberlanjutan mata pencaharian mereka. Namun masih ada kesenjangan antara masyarakat yang memiliki tingkat aset rendah yang merasa sulit untuk berpartisipasi dalam pariwisata, sehingga menerima lebih sedikit manfaat dengan orang kaya yang memiliki modal untuk berpartisipasi. Peran pemerintah, yaitu: pemerintah kotamadya atau kabupaten diperlukan untuk mendistribusikan bagian manfaat pariwisata di dalam komunitas pedesaan. Dengan cara ini, kesenjangan pendapatan yang meningkat dapat dikurangi dan potensi risiko lingkungan dan sosial dapat dikurangi. Produk pertanian lokal dapat dikembangkan yang dapat dilihat, dicicipi, dan dibuat oleh wisatawan dengan dipandu oleh penduduk setempat. Produk budaya, seperti karya seni atau artefak lokal, dapat didemonstrasikan, ditafsirkan, dan dijual kepada wisatawan untuk meningkatkan kesadaran budaya dan manfaat ekonomi. Penelitian mendukung hubungan antara pariwisata dan sistem mata pencaharian memandu eksplorasi kontribusi pariwisata untuk mata pencaharian pedesaan [8].

Penelitian yang berjudul "Revitalizing Traditional Villages Through Rural Tourism: A Case Study of Yuanjia Village, Shaanxi Province, China", Penulis Jing Gao dan Bihu Wu dalam Tourism Management (2017) menyatakan tujuan dari artikel ini adalah mengusulkan Model Revitalisasi Desa Adat Berbasis Wisata Pedesaan yang integratif dan berkelanjutan untuk lebih memahami hubungan antara desa wisata dan revitalisasi desa. Penelitian ini merupakan penelitian kualitatif dengan studi kasus, menggunakan metode wawancara, observasi, dan menggunakan Teori Pariwisata Pedesaan Terpadu dan Mata Pencaharian Berkelanjutan.

Penelitian ini menjelaskan desa-desa tradisional di Tiongkok mempunyai warisan berwujud dan tidak berwujud, masyarakat adat masih tinggal di sana, terlibat dalam kegiatan mata pencaharian tetapi urbanisasi mengakibatkan hilangnya desa dan hilangnya populasi. Dengan pariwisata pedesaan telah menjadi sarana utama melestarikan Kembali desa-desa tersebut (Fleischer \& Pizam, 1997; Balai, 2000; Luloff dkk., 1994). 
Tiga tingkat material, sosial, dan spiritual berkembang selangkah demi selangkah dan beredar sesuai dengan prinsip Siklus Hidup Area Wisata, menunjukkan bagaimana sebuah desa dapat eksis secara berkelanjutan. Model ini juga sesuai dengan Hirarki Kebutuhan Maslow, dari kebutuhan material yang rendah hingga aspirasi spiritual yang tinggi. Studi ini menjelaskan hubungan antara Wisata Pedesaan Terpadu dan revitalisasi desa, di mana Desa Yuanjia menjadi contoh keberhasilan revitalisasi desa tradisional melalui desa wisata. Untuk menciptakan lingkungan alam yang lebih baik, lahan pertanian yang luas akan dikembangkan untuk menawarkan kegiatan pengalaman bertani dan untuk memulihkan fungsi produksi lahan untuk tujuan ketahanan lingkungan. Desa Yuanjia juga berada di jalan menuju komunitas pedesaan yang harmonis, tenang, sehat, tradisional, dan modern [9].

\section{METODOLOGI}

Lokasi penelitian ini adalah di Desa Tista Kecamatan Kerambitan, Desa Bongan Kecamatan Tabanan, dan Desa Penatahan Kecamatan Penebel, dan semuanya di Kabupaten Tabanan, Provinsi Bali. Penelitian ini menggunakan metode kualitatif dengan menguraikan secara rinci tentang cara, instrumen, dan teknik analisis penelitian yang digunakan dalam memecahkan permasalahan. Metode pengumpulan data yang digunakan dalam penelitian ini adalah: 1) Observasi langsung ke lokasi penelitian untuk melihat secara langsung situasi riil di lapangan dan fenomena yang terjadi; 2) Wawancara mendalam dengan pelaku-pelaku langsung pengelola desa wisata, tokoh-tokoh masyarakat, kelompok-kelompok usaha masyarakat, serta dengan beberapa masyarakat terkait dengan manfaat pengembangan desa wisata; 3) Studi pustaka, yaitu: mengutip konsep-konsep terkait dengan desa wisata, partisipasi masyarakat, pariwisata berkelanjutan, serta konsep-konsep terkait pengelolaan destinasi sebagai rujukan melalui jurnal-jurnal, buku, hasil penelitian sebelumnya, dan sumber-sumber lainnya; serta 4) Focus Group Discussion (FGD) yang dipadukan dengan memberikan daftar pertanyaan/angket kepada beberapa tokoh yang memahami terkait pengelolaan dan pengembangan desa wisata, karakteristik daerah yang dikembangkan, pola kehidupan sosial masyarakat, adat, budaya, dan tradisi setempat, sehingga didapatkan sebuah gambaran yang jelas dan utuh terkait permasalahan dalam penelitian ini. [10].

Teknik analisis data yang digunakan adalah deskriptif kualitatif dan Analisis Skala Likert, di mana menggambarkan fenomena yang terjadi pada objek penelitian kemudian mengkaitkannya dengan fenomena-fenomena yang terjadi saat ini melalui interpretasi yang jelas dan akurat yang dideskripsikan secara sistematis dan runut dalam suatu kualitas yang mendekati kenyataan. Hasil analisis yang digunakan tentang manfaat pengembangan desa wisata di Kabupaten Tabanan dipakai suatu pedoman untuk menentukan sasaran yang akan dicapai dan memberikan gambaran yang jelas [11] [12].

\section{HASIL DAN PEMBAHASAN}

Desa Tista, Kecamatan Kerambitan, Desa Bongan, Kecamatan Tabanan, dan Desa Penatahan, Kecamatan Penebel, adalah desa yang terletak di wilayah Kabupaten Tabanan, Provinsi Bali. Adapun manfaat pengembangan desa wisata meliputi empat aspek yaitu aspek alam, aspek sosial budaya, aspek spiritual, dan aspek ekonomi yang dijelaskan sebagai beriktu. 


\section{Manfaat Pengembangan Desa Wisata Terhadap Aspek Alam}

Manfaat desa wisata dari aspek alam didapatkan beberapa poin penting yang menjadi indikator manfaat pengembangan Desa Wisata Tista, Desa Wisata Bongan, dan Desa Wisata Penatahan terhadap alam/lingkungan, di mana selain alam dan lingkungan dapat dijadikan daya tarik wisata juga sebagai tempat mata pencaharian masyarakat desa karena kehidupan di desa masih dominan merupakan kehidupan agraris, di mana faktor alam dan lingkungan ini sangat penting dan merupakan faktor utama. Di samping itu, kehidupan keseharian masyarakat (way of life) juga tidak bisa lepas dari ketersediaan dan kelestarian alam dan lingkungan. Sehingga, dapat disajikan beberapa manfaat desa wisata dari aspek alam, yaitu:

1. Mengurangi alih fungsi lahan,

2. Terjaganya kawasan konservasi,

3. Terjaganya sumber-sumber air,

4. Kepedulian terhadap alam meningkat,

5. Terjaganya kualitas lingkungan,

6. Mengurangi tingkat pencemaran, dan

7. Kesadaran masyarakat dalam membuang sampah.

Poin-poin tersebut merupakan hasil kompilasi dari ketiga desa yang menyatakan bahwa manfaat dari aspek alam tersebut ada tujuh poin. Dari ketujuh poin manfaat desa wisata tersebut, indikator-indikator yang dominan manfaatnya sampai yang paling rendah dapat dilihat pada Diagram 4.1. berikut.

\section{Diagram 4.1.}

\section{Manfaat Desa Wisata dari Aspek Alam}

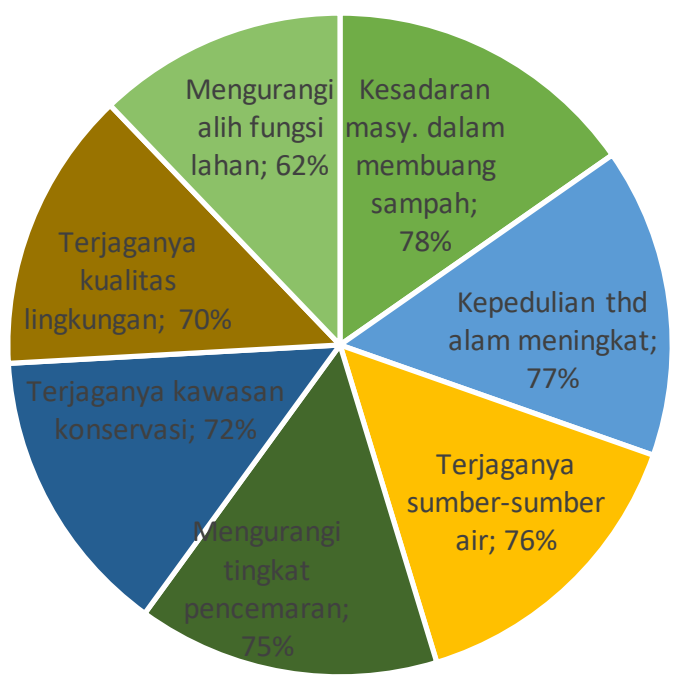

Sumber: Hasil Olahan Data, 2021 
Dilihat dari Diagram 4.1. tersebut bahwa manfaat desa wisata terhadap aspek alam yang paling besar adalah kesadaran masyarakat dalam membuang sampah sebesar 78\%, hal ini mengidentifikasikan bahwa masyarakat mulai menyadari dengan masalah klasik dalam pariwisata Bali, yaitu masalah sampah, sehingga untuk dapat berpartisipasi secara aktif dan meminimalisasi permasalahan sampah ini yang sudah sangat klasik, maka masyarakat di desa wisata mulai bergerak mulai dari desa, mulai dari tingkat lokal menggugah kesadaran dalam membuang sampah. Kaitan dengan kesadaran membuang sampah tersebut, maka berimbas kepada kepedulian terhadap alam meningkat (77\%), terjaganya sumber-sumber air (76\%), selanjutnya mengurangi tingkat pencemaran (75\%), terjaganya kawasan konservasi (72\%), terjaganya kualitas lingkung an $(70 \%)$, dan mengurangi alih fungsi lahan (62\%).

\section{Manfaat Pengembangan Desa Wisata Terhadap Aspek Sosial Budaya}

Manfaat pengembangan desa wisata dari aspek sosial budaya didapatkan beberapa poin penting yang menjadi indikator manfaat pengembangan Desa Wisata Tista, Desa Wisata Bongan, dan Desa Wisata Penatahan terhadap kehidupan sosial budaya masyarakat, di mana kehidupan sosial di desa masih sangat mengedepankan dan kental sistem kekeluargaan dan kegotongroyongannya yang melandasi setiap aktivitas di desa. Dari ketiga desa tersebut, masing-masing mempunyai budaya-budaya yang unik dan khas, sehingga keunikan dan kekhasannya tersebut dapat menjadi daya tarik wisata yang spesifik yang hanya dapat ditemukan dan disaksikan pada masing-masing desa tersebut. Sebagai contoh budaya yang unik dan spesifik, yaitu: Tari Andir yang merupakan tarian sakral dan hanya dapat disaksikan di Desa Wisata Tista, di mana penarinya adalah masih gadis dan dengan syarat-syarat khusus dan tidak boleh sembarang orang untuk menarikannya [13], Tradisi Mesuryak yang dilaksanakan pada Hari Raya Kuningan setiap enam bulan sekali yang merupakan budaya unik dan spesifik untuk mengucapkan rasa syukur atas anugerah Para Leluhur telah memberikan kelancaran dan keselamatan dalam menjalankan rangkaian Hari Raya Galungan dan Kuningan, di mana tradisi ini hanya dapat disaksikan di Desa Wisata Bongan [14], dan Tradisi Meayu-Ayu yang merupakan bentuk rasa syukur masyarakat terhadap melimpahnya hasil pertanian masyarakat, di mana budaya atau tradisi ini dilaksanakan secara berturut-turut selama tujuh hari penuh [15]. Sehingga, dapat disajikan beberapa manfaat pengembangan desa wisata dari aspek sosial budaya, yaitu:

1. Menghormati tradisi dan budaya,

2. Usaha menjaga tradisi dan budaya,

3. Pengenalan tradisi dan budaya,

4. Aktivitas tradisi dan budaya meningkat,

5. Regenerasi pelaku tradisi dan budaya,

6. Pementasan tradisi dan budaya, dan

7. Kekeluargaan dan kegotong-royongan meningkat.

Poin-poin tersebut merupakan hasil kompilasi dari ketiga desa yang menyatakan bahwa manfaat dari aspek sosial budaya tersebut ada tujuh poin. Dari ketujuh poin manfaat desa wisata tersebut, indikator-indikator yang dominan manfaatnya sampai yang paling rendah dapat dilihat pada Diagram 4.2. berikut. 
Diagram 4.2.

Manfaat Desa Wisata dari Aspek Sosial Budaya

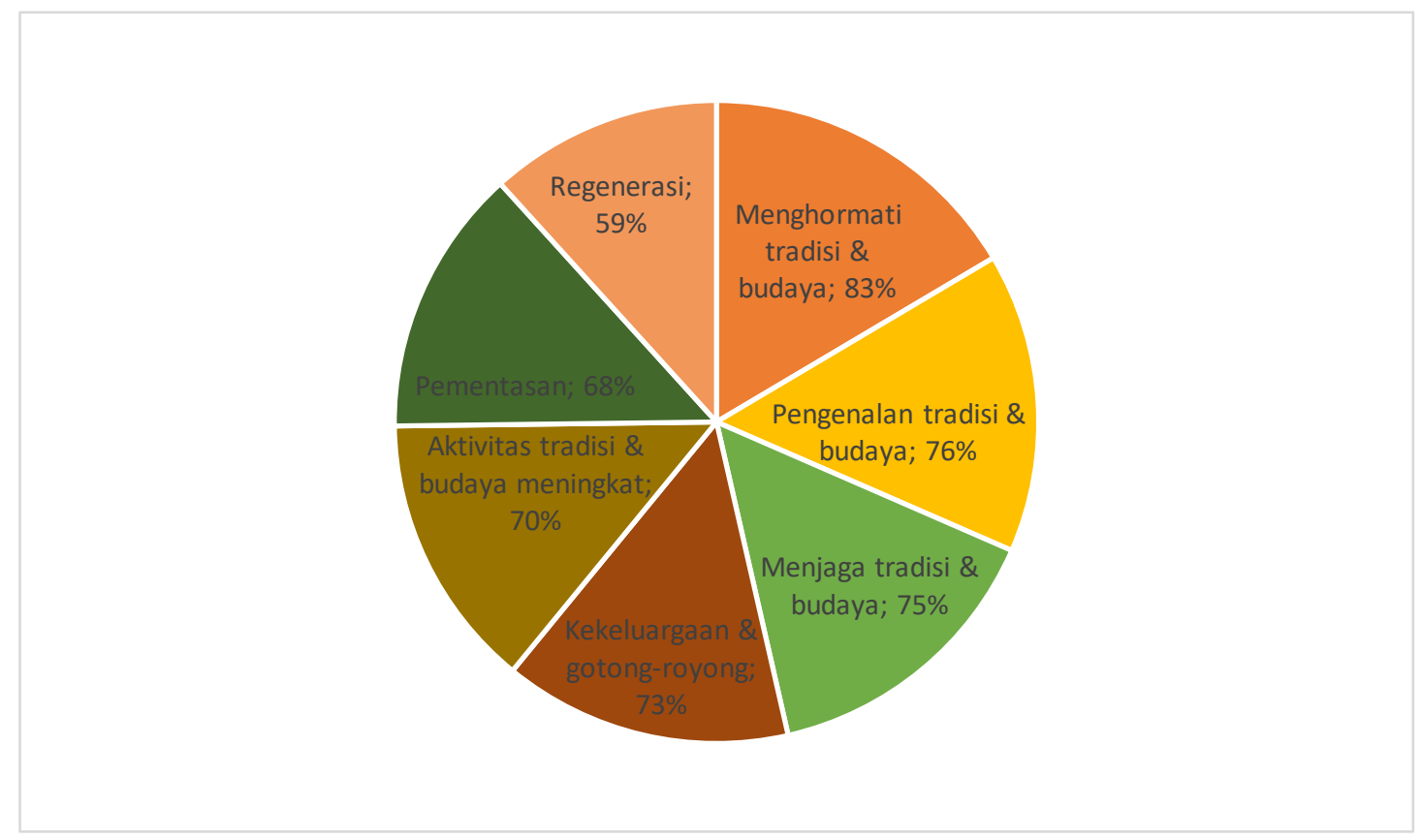

Sumber: Hasil Olahan Data, 2021

Dilihat dari Diagram 4.2. tersebut bahwa manfaat pengembangan desa wisata terhadap aspek sosial budaya yang tertinggi adalah menghormati tradisi dan budaya (83\%), di mana Kabupaten Tabanan merupakan daerah agraris yang merupakan lumbung berasnya Pulau Bali, sehingga mendapatkan pengakuan dari UNESCO terkait dengan subak sebagai Warisan Budaya Dunia. Dalam kehidupan agraris tradisi dan budaya sangat kental di masyarakat, sehingga tradisi dan budaya ini menjadi sebuah pedoman atau roh kehidupan sosial masyarakat. Di samping itu, tradisi dan budaya ini dikemas menjadi daya tarik wisata pada desa wisata di Kabupaten Tabanan, sehingga masyarakat sangat menghormati tradisi dan budaya ini. Usaha-usaha untuk menghormati tradisi dan budaya ini adalah pengenalan tradisi dan budaya (76\%), adanya usaha menjaga tradisi dan budaya $(75 \%)$, rasa kekeluargaan dan kegotongroyongan masyarakat meningkat (73\%), aktivitas dan pementasan tradisi dan budaya meningkat (70\%), dan adanya usaha meregenerasi pelaku tradisi dan budaya (59\%).

\section{Manfaat Pengembangan Desa Wisata Terhadap Aspek Spiritual}

Manfaat pengembangan desa wisata dari aspek spiritual didapatkan beberapa poin penting yang menjadi indikator manfaat pengembangan Desa Wisata Tista, Desa Wisata Bongan, dan Desa Wisata Penatahan terhadap kehidupan spiritual masyarakat, di mana praktek spiritual masyarakat desa berjalan secara rutin dan sudah menjadi sebuah kebiasaan yang diwariskan oleh Leluhur mereka dan sampai sekarang masih dijalankan dengan kuat. Dari ketiga desa tersebut hampir sama sistem keyakinan dan kepercayaannya terhadap Leluhur, Ida Betara, dan Dewa-Dewi. Aktivitas spiritual itu merupakan pengejawantahan dari rasa hormat, rasa terima kasih, rasa bakti, dan rasa syukur terhadap apa yang sudah didapatkan secara umum, baik itu berupa rejeki, berupa kesehatan, berupa umur panjang, berupa kedamaian dan kebahagiaan, berupa materi, dan berupa terkabulnya 
harapan-harapan dan permintaan-permintaan yang disampaikan melalui doa. Sehingga, dapat disajikan beberapa manfaat pengembangan desa wisata dari aspek spiritual, yaitu:

1. Kelestarian Tempat Suci,

2. Perawatan Tempat Suci,

3. Pelaba Pura terjaga,

4. Diperkuatnya aturan Tempat Suci,

5. Keberadaan Mitos terjaga,

6. Upacara digelar secara rutin, dan

7. Keyakinan beragama meningkat.

Poin-poin tersebut merupakan hasil kompilasi dari ketiga desa yang menyatakan bahwa manfaat dari aspek spiritual tersebut ada tujuh poin. Dari ketujuh poin manfaat desa wisata tersebut, indikator-indikator yang dominan manfaatnya sampai yang paling rendah dapat dilihat pada Diagram 4.3. berikut.

\section{Diagram 4.3.}

\section{Manfaat Desa Wisata dari Aspek Spiritual}

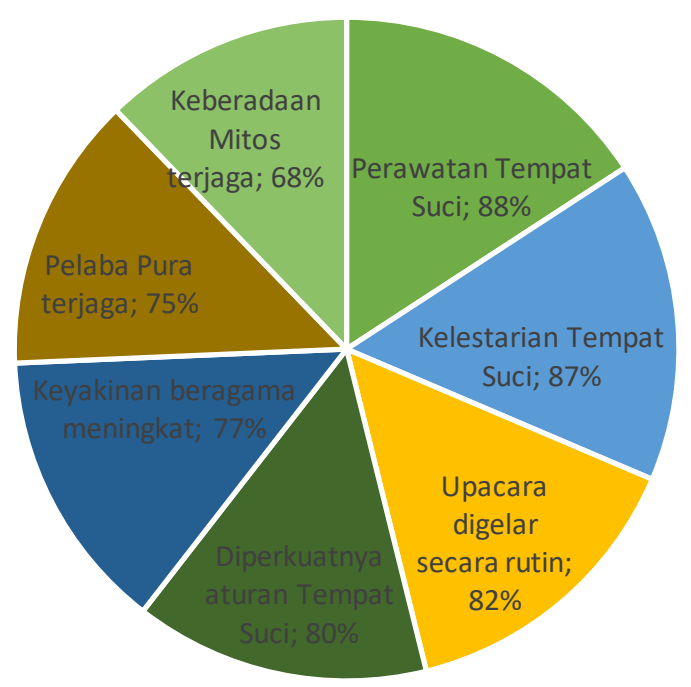

Sumber: Hasil Olahan Data, 2021

Dilihat dari Diagram 4.3. tersebut bahwa manfaat pengembangan desa wisata terhadap aspek spiritual yang tertinggi adalah perawatan Tempat Suci (88\%), hal ini seiring dengan tumbuhnya keyakinan dan kepercayaan masyarakat terhadap agama yang dianut, dalam hal ini adalah Agama Hindu. Tempat Suci yang ada di masing-masing desa wisata menjadi perhatian masyarakat sebagai sumber energi spiritual yang mengayomi dan menganugerahkan keselamatan dan kesejahteraan untuk masyarakat di desa wisata. Rasa terima kasih dan rasa syukur masyarakat diimplementasikan dengan merawat Tempat Suci yang ada dengan baik dan penuh rasa keikhlasan. Selanjutnya masyarakat tetap menjaga kelestarian Tempat Suci (87\%), Upacara Agama dilaksanakan secara 
rutin $(82 \%)$, keyakinan beragama masyarakat meningkat (77\%), Pelaba Pura terjaga (75\%), dan keberadaan mitos juga tetap terjaga (68\%).

\section{Manfaat Pengembangan Desa Wisata Terhadap Aspek Ekonomi}

Manfaat pengembangan desa wisata dari aspek ekonomi didapatkan beberapa poin penting yang menjadi indikator manfaat pengembangan Desa Wisata Tista, Desa Wisata Bongan, dan Desa Wisata Penatahan terhadap kehidupan ekonomi masyarakat, di mana sebagian besar kehidupan masyarakat adalah kehidupan agraris yang besarannya hampir 51\%, sehingga lahan-lahan pertanian dan perkebunan ini serta ikutannya, seperti: lahan-lahan perikanan dan peternakan juga menjadi gantungan hidup masyarakat. Sektor kerajinan dan sektor industri rumah tangga juga menjadi tambahan pendapatan masyarakat desa. Perkembangan desa wisata tentunya akan membawa dampak positif terhadap perekonomian masyarakat karena imbas atau energi penggerak dari sektor pariwisata ini apabila dikelola dengan baik akan dapat menyentuh semua sektor-sektor perekonomian di masyarakat. Perkembangan pariwisata melalui desa wisata ini membawa angin segar tumbuh berkembangnya ekonomi kreatif masyarakat pedesaan melalui efek-efek stimulus dan juga memberikan peluang untuk melipatgandakan hasil-hasil kegiatan agraris masyarakat apabila masyarakat kreatif dalam mengolah dan menciptakan produk-produk inovatif yang berkualitas dari bahan-bahan lokal yang ada di desa wisata masing-masing. Produk-produk olahan yang sudah dikemas dan dipasarkan inilah yang akan memberikan keuntungan berlipat kepada masyarakat, daripada hanya menjual hasil-hasil yang berupa bahan-bahan mentah saja [16]. Sehingga, dapat disajikan beberapa manfaat pengembangan desa wisata dari aspek ekonomi, yaitu:

1. Lapangan kerja terbuka,

2. Mata pencaharian terjaga,

3. Kewirausahaan meningkat,

4. Pendapatan masyarakat meningkat,

5. Tumbuhnya UMKM,

6. Branding produk meningkat, dan

7. Kemiskinan menurun.

Poin-poin tersebut merupakan hasil kompilasi dari ketiga desa yang menyatakan bahwa manfaat dari aspek ekonomi tersebut ada tujuh poin. Dari ketujuh poin manfaat desa wisata tersebut, indikator-indikator yang dominan manfaatnya sampai yang paling rendah dapat dilihat pada Diagram 4.4. berikut. 


\section{Diagram 4.4. \\ Manfaat Desa Wisata dari Aspek Ekonomi}

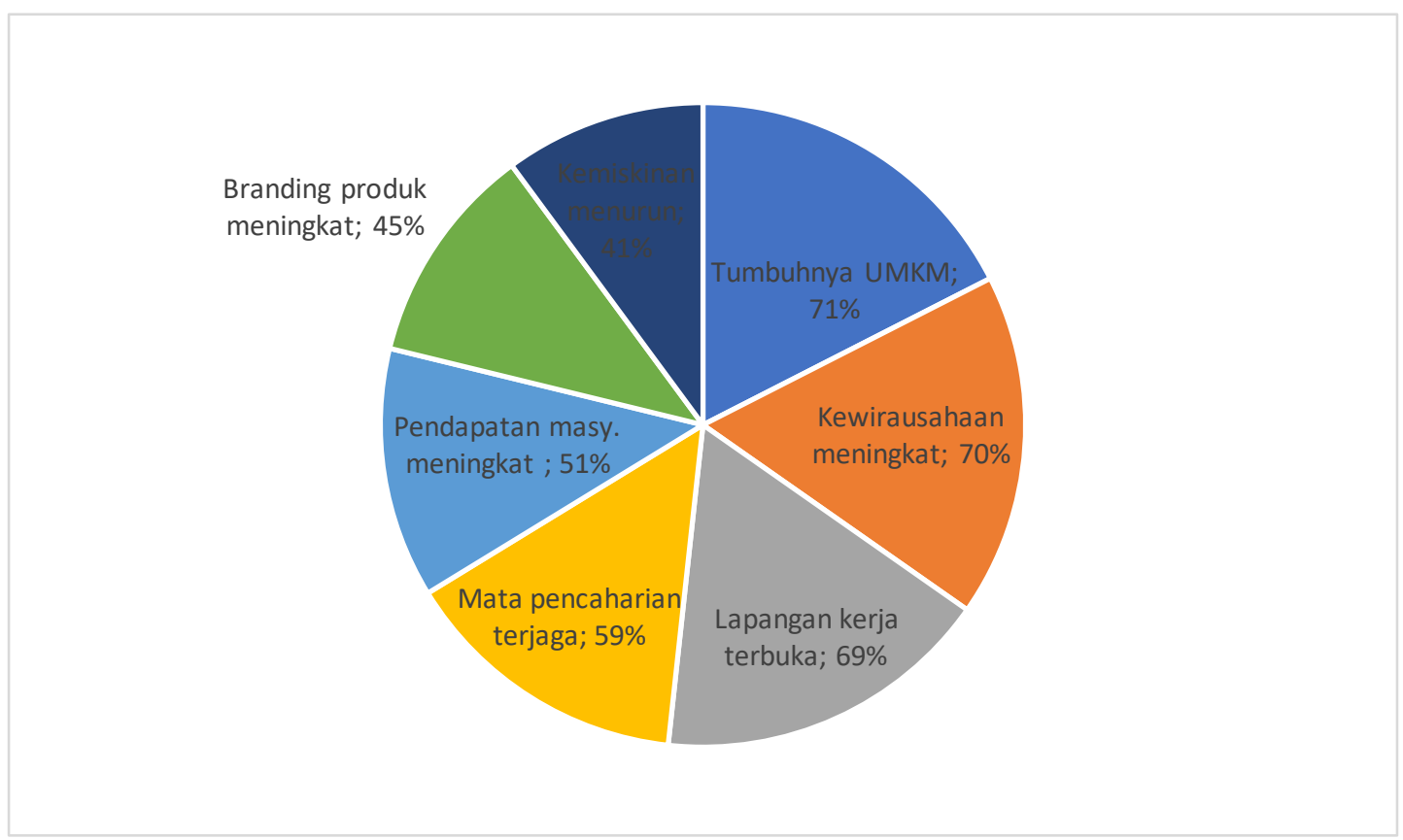

Sumber: Hasil Olahan Data, 2021

Dilihat dari Diagram 4.4. tersebut bahwa manfaat pengembangan desa wisata terhadap aspek ekonomi ini yang tertinggi adalah tumbuhnya UMKM (71\%), di mana di masa Pandemi Covid-19 ini banyak tenaga kerja di sektor pariwisata yang dirumahkan bahkan di PHK, sehingga mereka saat ini kembali pulang ke desanya masing-masing, sehingga untuk dapat melanjutkan kehidupannya, sebagian besar diantara masyarakat yang membuka usaha atau kegiatan kewirausahaan, sehingga mulai tumbuh UMKM di desa-desa wisata. Produk-produk lokal yang dulunya dilupakan, saat ini mulai digali dan dibangkitkan lagi sebagai produk-produk usaha masyarakat, sepertia: memproduksi jajan-jajan Bali, membuka asaha makanan tradisional, mengkemas produk -produk dari bahan-bahan lokal, seperti: keripik keladi, abon bungkil pisang, kerajinan-kerajinan, seperti: pot dari batok kelapa, kerajinan-kerajinan dari bambu, lukisan-lukisan tradisional, dan lain-lain yang nilai ekonomisnya tidak kalah dengan produk-produk pabrikan. Selanjutnya kewirausahaan meningkat (70\%), lapangan kerja terbuka (69\%), mata pencaharian terjaga (59\%), pendapatan masyarakat meningkat (51\%), branding produk meningkat (45\%), dan kemiskinan menurun $(41 \%)$.

\section{KESIMPULAN}

Dari hasil pemaparan tersebut, maka dapat disimpulkan terkait manfaat pengembangan desa wisata dari aspek alam, aspek sosial budaya, aspek spiritual, dan aspek ekonomi sebagai berikut: Aspek Alam: mengurangi alih fungsi lahan, terjaganya kawasan konservasi, terjaganya sumbersumber air, kepedulian terhadap alam meningkat, terjaganya kualitas lingkungan, mengurangi tingkat pencemaran, dan kesadaran masyarakat dalam membuang sampah; Aspek Sosial Budaya: menghormati tradisi dan budaya, usaha menjaga tradisi dan budaya, pengenalan tradisi dan budaya, aktivitas tradisi dan budaya meningkat, regenerasi pelaku tradisi dan budaya, pementasan tradisi 
dan budaya, dan kekeluargaan dan kegotong-royongan meningkat; Aspek Spiritual: kelestarian Tempat Suci, perawatan Tempat Suci, Pelaba Pura terjaga, diperkuatnya aturan Tempat Suci, keberadaan Mitos terjaga, Upacara digelar secara rutin, dan keyakinan beragama meningkat; dan Aspek Ekonomi: lapangan kerja terbuka, mata pencaharian terjaga, kewirausahaan meningkat, pendapatan masyarakat meningkat, tumbuhnya UMKM, branding produk meningkat, dan kemiskinan menurun.

\section{Ucapan terima kasih}

Ucapan terima kasih kepada Bapak Rektor, Para Wakil Rektor, Ketua LPPM beserta staf, Bapak Dekan beserta Para Wakil Dekan, Staf Administrasi Fakultas Pariwisata Universitas Udayana, dan teman-teman sejawat serta masyarakat Desa Tista, Desa Bongan, dan Desa Penatahan, Kecamatan Penebel, Kabupaten Tabanan yang sudah mendukung dalam penyelesaian tulisan ini.

\section{DAFTAR PUSTAKA}

[1] Cawley, Mary dan Gillmor, Desmond. 2008. Integrated Rural Tourism: Concepts and Practice. Annals of Tourism Research, Vol. 35, No. 2, pp. 316-337.

[2] Antara, Made. 2016. Panduan Tata Kelola Desa Wisata Kenderan. Denpasar: Pelawa Sari.

[3] Maksimilianus, Ardiyanto, dkk. 2020. Perencanaan dan Pengembangan Desa. Malang: Dream Litera.

[4] Aliyah, Istijabatul. 2020. Desa Wisata Berwawasan Ekobudaya. Surakarta: Yayasan Kita Menulis.

[5] Chaiyakot, Prachyaakorn dan Visuthismajarn, Parichart. 2012. A Pattern of Rural Tourism In The Songkhla Lake Basin, Thailand. International Journal of Management \& Information Systems, Volume 16, Number 2.

[6] Su, Wei-Sun. 2017. Cittaslow: A New Pattern of Sustainable Tourism Development in Taiwan. The

International Journal of Organizational Innovation Vol. 9 Num 4.

[7] Li, Ping (et.al). 2016. Chinese Rural Tourism Development: Transition in The Case of Qiyunshan, Anhui. Tourism Management.

[8] Ming Sua, Ming (et.al). 2019. Livelihood Sustainability in A Rural Tourism Destination Hetu Town, Anhui Province, China. Tourism Management, 272 - 282.

[9] Gao, Jing dan Wu, Bihu. 2017. Revitalizing Traditional Villages Through Rural Tourism: A Case Study of Yuanjia Village, Shaanxi Province, China. Tourism Management.

[10] Chalil, Diana. 2014. Analisis Data Kualitatif. Medan: USU Press. 
[11] Sugiyono. 2013. Metode Penelitian Kuantitatif, Kualitatif, dan $R \&$ D. Bandung: Alfabeta.

[12] Raco, R. 2010. Metode Penelitian Kualitatif: Jenis, Karakteristik, dan Keunggulannya. Jakarta: Gramedia.

[13] IM. Suardana Putra. 2021. "Wawancara dengan I Made Suardana Putra, Kepala Desa Tista, Tanggal 18 September 2021".

[14] IK. Sukarta. 2021. "Wawancara dengan I Ketut Sukarta, Kepala Desa Bongan, Tanggal 29 September 2021".

[15] IN. Suartika. 2021. "Wawancara dengan I Nengah Suartika, Kepala Desa Penatahan, Tanggal 09 Oktober 2021".

[16] IN. Sangka. 2021. "Wawancara dengan I Nyoman Sangka, Ketua Pokdarwis Desa Wisata Tista, Tanggal 16 Oktober 2021". 